\title{
THE IMPACT OF TELEVISION ADVERTISEMENTS ON STUDENT DECISION-MAKING PROCESS FOR COLLEGE ADMISSION: AN EXPLORATORY STUDY IN INDIA
}

\author{
Gautam S Bapat*1, Prema Mahale2, Arya Kumar33, Raghavan Srinivasan4 \\ 1. MIT World Peace University, School of Management, Pune, India \\ 2. Vivekanand Institute of Management Studies and Research, Mumbai University, India \\ 3. KIIT School of Commerce and Economics, Kalinga Institute of Industrial Technology (Deemed to be University), Bhubaneswar, \\ India \\ 4. All India Management Association, Aligarh Muslim University, India
}

Correspondence: gautambapat@yahoo.co.in

\begin{abstract}
COVID-19 drove universities throughout the world forcing Higher Education Institutions (HEls) to go online or virtual. Admissions advertising and student recruitment were two of the sectors that were severely hit. Internet-based advertising has to entirely replace the old advertising environment. Although certain institutions were still able to conduct virtual tours, forums, and information sessions, the amount of involvement differed among colleges and universities. An exploratory study was conducted to investigate how effective Internet advertisements were in influencing students' admission decisions. During the academic year, 2020-21 at several institutions in India's western region, data were collected using the snowball sampling approach on 930 freshly enrolled students. The findings show that the efficacy of Internet ads for university admission is negatively correlated with the student's age group. Surprisingly, the study discovered that both rural and urban students were equally interested in online ads, and that family background had no impact on receptiveness to internet advertisements.
\end{abstract}

\subsection{KEYWORDS}

University Admissions; COVID-19; Internet Advertisements; Pandemic; Student Recruitments.

\section{INTRODUCTION}

The COVID-19 outbreak forced universities and other academic organisations to respond quickly to lifethreatening conditions [1][2]. Most universities were compelled to shut down almost every element of their research and teaching operations as a result of it. [1] [3]
Although institutions were able to shift to virtual offerings in a very short period and assist students in completing their degree programmes online, universities and colleges struggled to admit and enrol new students. [4] [5][6][7] Due to the lockdown scenario during the Covid-19 epidemic, university marketers' conventional strategies were disrupted. [8] 
Because the Internet is a more engaging medium, it may have a significant influence on students' admissions decisions. [8-11] Online channels such as Facebook, Twitter, Instagram, YouTube, and email, to mention a few, are included in the word "internet". [12] [13] To reach out to potential students, schools and universities are increasingly employing Internet ads as part of their marketing plan. [7]

The influence of online advertising on students' admissions decision-making has been studied by academics. In emerging countries, the amount of internet advertising is rapidly increasing. [13-15] Marketers have put a lot of money into different digital channels that influence customer behaviour. [16] [17] Consumer media habits have shifted dramatically as a result of the digitization of communication channels. [18] As a result, it's crucial to understand how young potential students react to the different communication channels utilised by higher education marketers in India. [19] [20] An exploratory study was conducted to determine the influence of Internet advertisements on students' admissions decision-making process.

\section{RESEARCH FRAMEWORK}

In 1981, Chapman conducted a review of the literature on college selection and developed a model to "assist college administrators responsible for recruitment policy in identifying the pressures and influences they must consider in developing institutional recruiting policy, as well as to aid continued research in the area of student college choice". [21]

FIGURE 1 CHAPMAN, D. W. (1981). A MODEL OF STUDENT COLLEGE CHOICE [21]

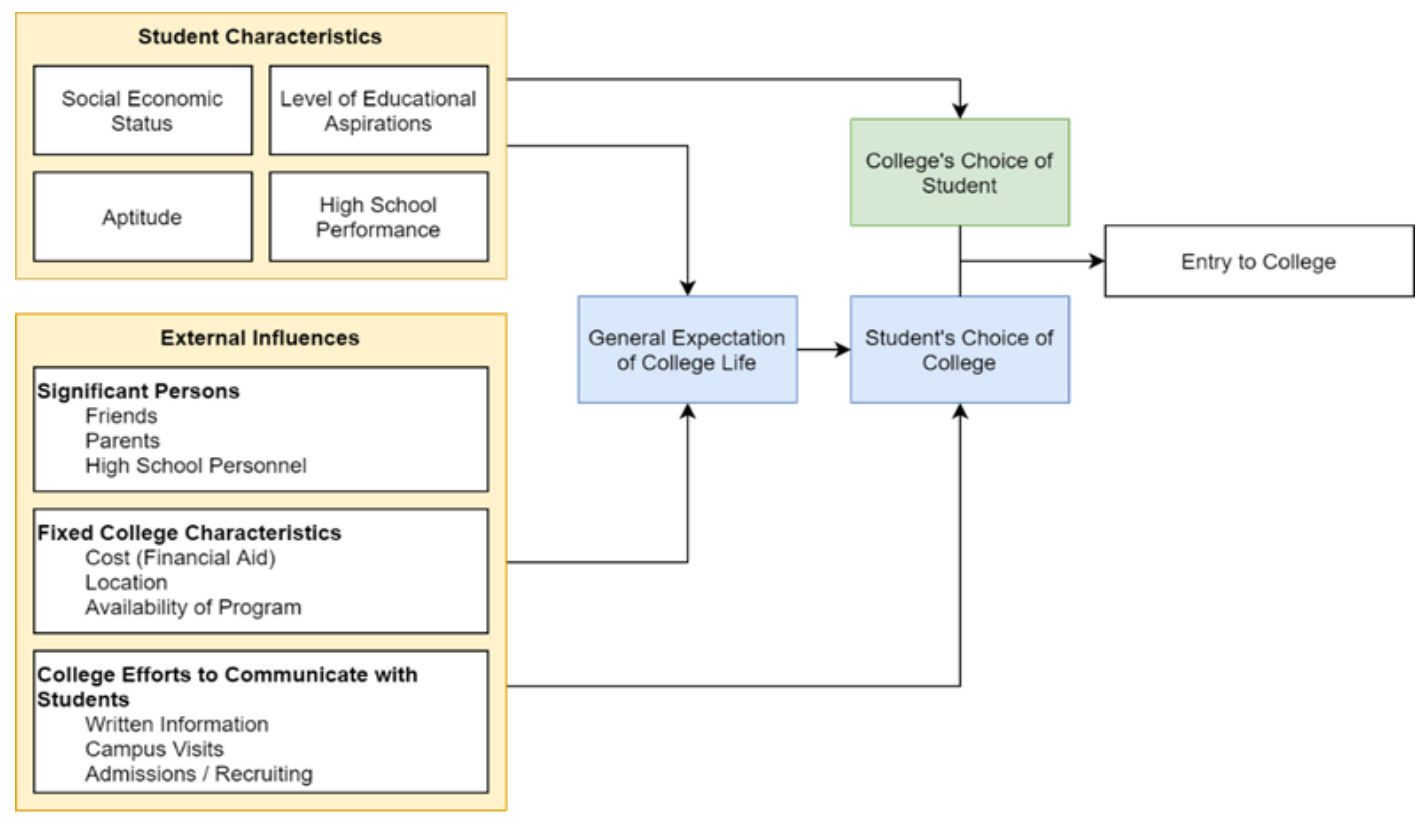

According to Chapman's approach, written communication, campus visits, and admissions and recruitment activities are all major external influencers, with the third being the college's attempts to connect with students. Below is the proposed model in this study:

FIGURE 2 PROPOSED RESEARCH MODEL

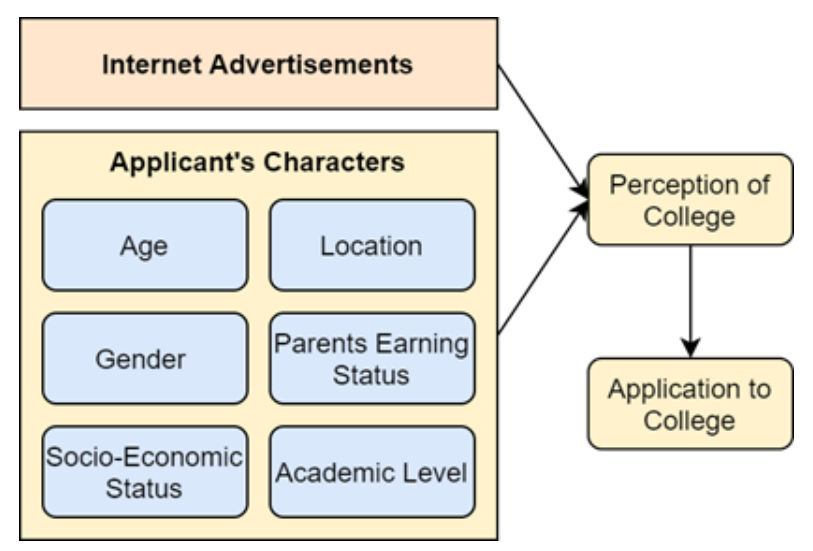




\section{DATA AND SAMPLE}

A convenience sample of 224 students was used to create and administer a structured questionnaire. The respondents were undergraduate and graduate students in India's western region. The survey was conducted entirely online. Only one response per student was taken into account. Due to incompleteness, partial replies were not included in the study, leaving 24 such responses. Finally, 200 responses were deemed to be suitable for further investigation.

\section{MEASURES}

The questionnaire had a total of 12 items, all of which were written in English. The items in the questionnaire were graded on a seven-point Likert scale that ranged from 1 Strongly Disagree to 7-Strongly Agree.

\section{DATA ANALYSIS}

The data was analysed using SPSS software. Cronbach's alpha value was used to assess the scales' internal consistency. Internal consistency reliability, which is assessed by alpha coefficient reliability or Cronbach Alpha, is used to assess the instrument's reliability. The Chi-Square test was used to evaluate the hypotheses.

\section{RESEARCH CONTEXT}

While extensive research has been done on the factors that impact students' educational goals and their decisions to enrol or not enrol in college, students' choice of school has received less attention. [4] [22] [23] The lack of research is due to several issues. During an era when college enrolments were soaring, college officials were unconcerned about particular consequences on students' college choices. [24-26] The emphasis in admissions was on selection rather than recruiting. [27] There hasn't been much theory to guide study into individual college selections. [28] [29] Researchers looked at undergraduate and postgraduate students who had recently applied for admission to several private universities for the academic year 2020-21.

\subsection{SAMPLING}

All domestic students who applied for admission to various graduate and undergraduate programmes in the academic year 2020-21 were included in the study. This study was done entirely in the English language. The study questionnaire responses were collected in the third quarter of 2020. The survey was distributed to 930 students, and 224 students answered, accounting for 24.08 per cent of the total. 200 replies $(n=200)$ were found suitable for further study after a thorough inspection and data cleansing.

\subsection{METHODOLOGY}

The frequency and percentages were used to express the analysis of Qualitative Data Variables. The Chi-Square test was performed to determine the relationship between various demographic factors and the study goal, which is University Advertisements on the Internet. Significant pvalues of less than 0.05 were evaluated.

\section{RESULTS}




\begin{tabular}{llll}
\hline \multirow{2}{*}{ Academic Level } & Postgraduate & 6 & $3.0 \%$ \\
& Undergraduate & 194 & $97.0 \%$ \\
\hline & Commerce & & \\
Faculty & Engineering & 31 & $15.5 \%$ \\
& Law & 1 & $0.5 \%$ \\
& Management & 167 & $0.5 \%$ \\
\hline
\end{tabular}

\subsection{STATISTICAL ANALYSIS OF THE IMPACT OF INTERNET ADVERTISEMENTS ON ADMISSIONS DECISION}

\begin{tabular}{llll}
\hline $\begin{array}{l}\text { Have you seen the Advertisement for } \\
\text { the University you are currently }\end{array}$ & No & $n$ & Percentage \\
studying in before taking Admissions & Yes & 35 & $17.5 \%$ \\
\hline & Not Appealing & 165 & $82.5 \%$ \\
How far the content of the Somewhat Appealing & 2 & $1.2 \%$ \\
Advertisement was effective towards & Moderately Appealing & 3 & $3.6 \%$ \\
admission decision & Highly Appealing & 38 & $23.0 \%$ \\
& Extremely Appealing & 61 & $37.0 \%$ \\
\hline \\
How far the design of the & Not Appealing & 58 & $35.2 \%$ \\
Advertisement was effective towards & Moderately Appealing & 3 & $1.8 \%$ \\
admission decision & Highly Appealing & 5 & $3.0 \%$ \\
& Extremely Appealing & 40 & $24.2 \%$ \\
\hline
\end{tabular}

\subsection{HYPOTHESIS TESTING}

Hypothesis No 1: HO There is no association between the age group of the respondents and their tendency to pay attention to internet advertisements of the universities of their interest.

\begin{tabular}{lllll}
\hline $\begin{array}{l}\text { Age Group of } \\
\text { Respondents }\end{array}$ & $\begin{array}{l}\text { Paid attention to internet advertisements of } \\
\text { the universities of their interest } \\
\text { No }\end{array}$ & Yes & Total & p-value \\
\hline $\mathbf{1 8}$ & 15 & 116 & 131 & 0.999 \\
$\mathbf{1 8}$ & 3 & 23 & 26 & 157 \\
\hline Total & 18 & 139 & \\
\hline
\end{tabular}

The p-value of 0.999 indicates that there is no association between the age group of the respondents and their tendency to pay attention to internet advertisements of the universities of their interest. Hence, the Null Hypothesis is accepted.

Hypothesis No 2: HO There is no association between the Gender of the respondents and their tendency to pay attention to internet advertisements of the universities of their interest.

\begin{tabular}{|c|c|c|c|c|c|}
\hline \multirow{2}{*}{$\begin{array}{l}\text { Gender } \\
\text { Respondents }\end{array}$} & \multirow[t]{2}{*}{ the } & \multicolumn{2}{|c|}{$\begin{array}{l}\text { Paid attention to internet advertisements of } \\
\text { the universities of their interest }\end{array}$} & \multirow[t]{2}{*}{ Total } & \multirow[t]{2}{*}{ p-value } \\
\hline & & No & Yes & & \\
\hline Male & & 7 & 87 & 94 & \\
\hline Female & & 11 & 52 & 63 & 0.073 \\
\hline Total & & 18 & 139 & 157 & \\
\hline
\end{tabular}

The p-value of 0.073 indicates that there is no association between the Gender of the respondents concerning the tendency to pay attention to internet advertisements of the universities of their interest. Hence, the Null Hypothesis is accepted. 
Hypothesis No 3: $\mathrm{H}_{0}$ There is no association between the Socio-Economic Status of the family of the respondents and their tendency to pay attention to internet advertisements of the universities of their interest.

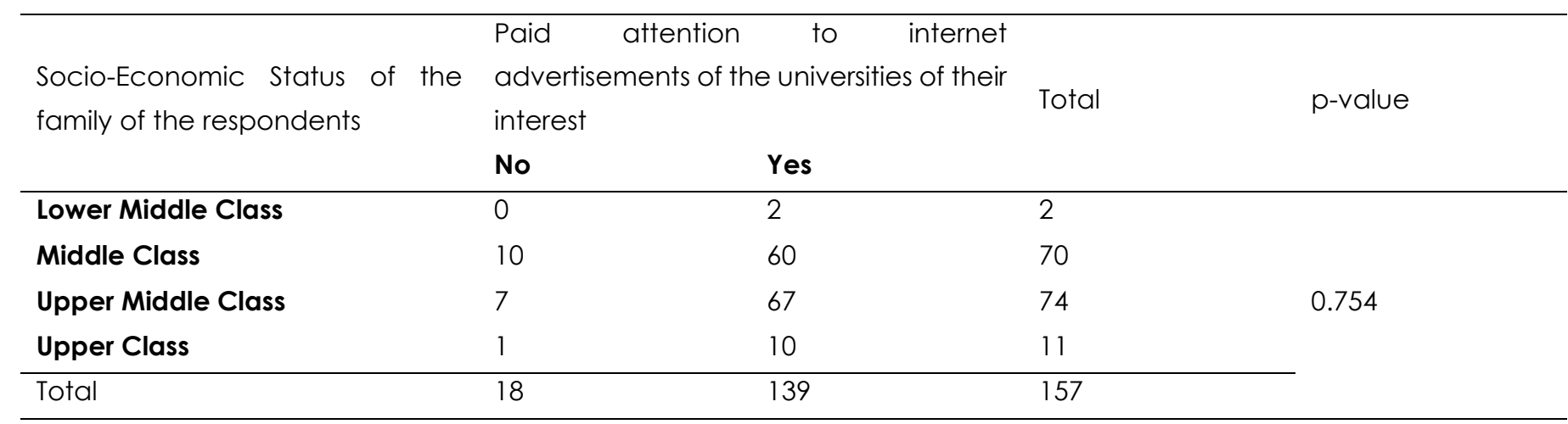

The p-value of 0.754 indicates that there is no association between the Socio-Economic Status of the family of the respondents concerning the tendency to pay attention to internet advertisements of the universities of their interest. Hence, the Null Hypothesis is accepted.

Hypothesis No 4: Ho There is no association between the Original Location of the respondents and their tendency to pay attention to internet advertisements of the universities of their interest.

\begin{tabular}{lllll}
\hline $\begin{array}{l}\text { Original Location of the } \\
\text { Respondents }\end{array}$ & $\begin{array}{l}\text { Paid attention to internet advertisements of } \\
\text { the universities of their interest } \\
\text { No }\end{array}$ & Yes & Total & P-value \\
\hline Rural India & 0 & 19 & 19 & 138 \\
Urban India & 18 & 120 & 157 & 0.131 \\
\hline Total & 18 & 139 & \\
\hline
\end{tabular}

The p-value of 0.131 indicates that there is no association between the Original Location of the respondents concerning the tendency to pay attention to internet advertisements of the universities of their interest. Hence, the Null Hypothesis is accepted.

Hypothesis No 5: Ho There is no association between the Earning Status of the Parents of the respondents and their tendency to pay attention to internet advertisements of the universities of their interest.

\begin{tabular}{lllll}
\hline $\begin{array}{l}\text { Earning Status of the Parents of the } \\
\text { respondents }\end{array}$ & $\begin{array}{l}\text { Paid advertisements of the universities of } \\
\text { their interest } \\
\text { No }\end{array}$ & Yes & Total & p-value \\
\hline Both Parent Earning & 2 & 38 & 40 & 117 \\
Single Parent Earning & 16 & 101 & 157 & 0.163
\end{tabular}

The p-value of 0.040 indicates that there is an association between the Earning Status of the Parents of the respondents concerning the tendency to pay attention to internet advertisements of the universities of their interest. Hence, the Null Hypothesis cannot be accepted.

Hypothesis No 6: Ho There is no association between the Academic Level of the respondents and their tendency to pay attention to internet advertisements of the universities of their interest.

\begin{tabular}{|c|c|c|c|c|}
\hline \multirow[t]{2}{*}{ Academic Level of the respondents } & $\begin{array}{l}\text { Paid } \\
\text { adve } \\
\text { their }\end{array}$ & $\begin{array}{l}\text { to internet } \\
\text { the universities of }\end{array}$ & Total & \multirow[t]{2}{*}{ p-value } \\
\hline & No & Yes & & \\
\hline Postgraduate & 1 & 0 & 1 & \multirow{3}{*}{0.115} \\
\hline Undergraduate & 17 & 139 & 156 & \\
\hline Total & 18 & 139 & 157 & \\
\hline
\end{tabular}

The p-value of 0.115 indicates that there is no association between the Academic Level of the respondents concerning the tendency to pay attention to internet advertisements of the universities of their interest. Hence, the Null Hypothesis is accepted. 
Hypothesis No 7: HO There is no association between the Academic Stream of the respondents and their tendency to pay attention to internet advertisements of the universities of their interest.

\begin{tabular}{|c|c|c|c|c|}
\hline \multirow[t]{2}{*}{ Academic Stream of the respondents } & \multicolumn{2}{|c|}{$\begin{array}{l}\text { advertisements of the universities of } \\
\text { their interest }\end{array}$} & \multirow[t]{2}{*}{ Total } & \multirow[t]{2}{*}{ p-value } \\
\hline & No & Yes & & \\
\hline Commerce & 1 & 26 & 27 & \multirow{4}{*}{0.295} \\
\hline Engineering & 0 & 1 & 1 & \\
\hline Management & 17 & 112 & 129 & \\
\hline Total & 18 & 139 & 157 & \\
\hline
\end{tabular}

The p-value of 0.295 indicates that there is no association between the Academic Level of the respondents concerning the tendency to pay attention to internet advertisements of the universities of their interest. Hence, the Null Hypothesis is accepted.

\section{DISCUSSION AND CONCLUSIONS}

After assessing all seven assumptions, researchers determined that the student's age had no effect on the effectiveness of Internet marketing for university enrolment. Graduate and postgraduate students had an interest in internet advertisements. As a result, while establishing higher education marketing strategy, bear in mind that whether you're advertising graduate-level or postgraduate-level material, your message will have the same impact.

Similarly, it was revealed that prospective students' gender, as well as their family's financial status, had no influence on their acceptance of internet advertising. Male and female students were equally interested in their ability to respond to internet advertisements. University adverts on the Internet were ecstatically received by families from the Lower Middle Class, Middle Class, Upper Middle Class, and Upper Class.

Researchers also looked into whether applicants' location in India (rural vs. urban) influenced their willingness to respond to university advertisements on the internet. Online advertisements piqued the interest of students in both rural and urban locations. Researchers also looked examined whether the financial status of the applicants' parents, whether both earn or one parent is the family's sole earner, had any influence on their receptivity to internet marketing.

\section{Reference}

1. C. Coyne, J. D. Ballard, and I. J. Blader, "Recommendations for future university pandemic responses: What the first COVID-19 shutdown taught us," PLoS Biology, vol. 18, no. 8. p. e3000889, Aug. 27, 2020, doi: 10.1371/journal.pbio.3000889.
2. G. Bapat, C. Ravikumar, and S. Shrivallabh, "An exploratory study to identify the important factor of the university website for admissions during covid- 19 crisis," J. Eng. Educ. Transform., vol. 35, no. 1, pp. $116-$ 120, 2021, doi: 10.16920/jeet/2021/v35i1/155961.

3. K. Usher, N. Bhullar, and D. Jackson, "Life in the pandemic: Social isolation and mental health," J. Clin. Nurs., vol. 29, no. 15-16, pp. 2756-2757, Aug. 2020, doi: $10.1111 /$ jocn.15290.

4. T. D. Le, L. J. Robinson, and A. R. Dobele, "Understanding high school students use of choice factors and word-of-mouth information sources in university selection," Stud. High. Educ., vol. 45, no. 4, pp. 808-818, Apr. 2020, doi: 10.1080/03075079.2018.1564259.

5. A. Ara Shaikh, A. Kumar, K. Jani, S. Mitra, D. A. GarcíaTadeo, and A. Devarajan, "The Role of Machine Learning and Artificial Intelligence for making a Digital Classroom and its sustainable Impact on Education during Covid-19," Mater. Today Proc., Sep. 2021, doi: 10.1016/j.matpr.2021.09.368.

6. A. Kumar, A. A. Syed, and A. Pandey, "Adoption of online resources to improve the marketing performance of SMES," Asia Pacific J. Heal. Manag., Nov. 2021, doi: 10.3316/INFORMIT.081159555237037.

7. A. KUmar, "SUSTAINABLE DEVELOPMENT THROUGH SOCIAL MEDIA TOOLS Sustainable Development through Social Media Tools," Nov. 2020.

8. M. K. Humlum, J. H. G. Kristoffersen, and R. Vejlin, "College admissions decisions, educational outcomes, and family formation," Labour Econ., vol. 48, pp. 215-230, Oct. 2017, doi: 10.1016/j.labeco.2017.08.008. 
9. B. J. Keegan and J. Rowley, "Evaluation and decision making in social media marketing," Manag. Decis., vol. 55, no. 1, pp. 15-31, Feb. 2017, doi: 10.1108/MD10-2015-0450.

10. A. Kusumavati, "Impact of Digital Marketing on Student Decision-Making Process of Higher Education Institution: A Case of Indonesia," J. e-Learning High. Educ., no. July, pp. 1-11, Jun. 2019, doi: $10.5171 / 2019.267057$.

11. K. Herold, J. Sipilä, A. Tarkiainen, and S. Sundqvist, "How service values influence the processing of wordof-mouth in the evaluation of credence beliefs," J. Mark. High. Educ., 2017, doi:

10.1080/08841241.2016.1213347.

12. U. R. Gottlieb and A. Beatson, "High on emotion! perceived value: influencing decision-making processes at international student recruitment trade shows," J. Mark. High. Educ., vol. 28, no. 2, pp. 282297, 2018, doi: 10.1080/08841241.2018.1476430.

13. R. V Kozinets, "E-tribalized marketing?: The strategic implications of virtual communities of consumption," Eur. Manag. J., vol. 17, no. 3, pp. 252-264, Jun. 1999 , doi: 10.1016/S0263-2373(99)00004-3.

14. A. B. Mohammed and M. Alkubise, "How do Online Advertisements Affects Consumer Purchasing Intention: Empirical Evidence from a Developing Country," Eur. J. Bus. Manag., vol. 4, no. 7, pp. 208218, 2012, [Online]. Available: http://www.iiste.org/Journals/index.php/EJBM/article/ view/1829/1782.

15. P. T. Mahajan and S. B. Golahit, "Engineering a Woman: Marketing Opportunities and Challenges in India," Am. J. Manag. Sci. Eng., vol. 2, no. 1, pp. 11-22, 2017, doi: 10.11648/j.ajmse.20170201.12.

16. R. Sama, "Impact of Media Advertisements on Consumer Behaviour," J. Creat. Commun., vol. 14, no. 1, pp. 54-68, Mar. 2019, doi: $10.1177 / 0973258618822624$.

17. J. Hemsley-Brown and I. Oplatka, "Universities in a competitive global marketplace: A systematic review of the literature on higher education marketing," Int. J. Public Sect. Manag., vol. 19, no. 4, pp. 316-338, 2006, doi: $10.1108 / 09513550610669176$.

18. G. S. Bapat, "Students recruitment strategies at higher educational institutes: A new world perspective - A review of the literature on higher education marketing," Int. J. Adv. Res. IDEAS Innov. Technol., vol.
5, no. 3, pp. 1860-1864, Jun. 2019, [Online]. Available: https://www.ijariit.com/manuscript/students-

recruitment-strategies-at-higher-educational-institutesa-new-world-perspective-a-review-of-the-literatureon-higher-education-marketing/.

19. J. Nagy, U. Demiray, and A. Yilmaz, "Strategies For The Marketing Of Higher Education With Comparative Contextual References Between Australia And Turkey," Turkish Online J. Distance Educ., vol. 8, no. 2, pp. 157-173, 2007, doi: 10.17718/tojde.81829.

20. E. Constantinides and M. C. Z. Stagno, "Potential of the social media as instruments of higher education marketing: A segmentation study," J. Mark. High. Educ., vol. 21, no. 1, pp. 7-24, 2011, doi: $10.1080 / 08841241.2011 .573593$.

21. D. W. Chapman, "A Model of Student College Choice," J. Higher Educ., vol. 52, no. 5, p. 490, Sep. 1981, doi: 10.2307/1981837.

22. D. Vrontis, A. Thrassou, and Y. Melanthiou, "A contemporary higher education student-choice model for developed countries," J. Bus. Res., vol. 60, no. 9, pp. 979-989, Sep. 2007, doi: 10.1016/j.jbusres.2007.01.023.

23. J. Posselt, T. E. Hernandez, C. D. Villarreal, A. J. Rodgers, and L. N. Irwin, "Evaluation and Decision Making in Higher Education," 2020, pp. 1-63.

24. M. Winn, L. Leach, S. Erwin, and L. Benedict, "Factors Affecting Graduate Educational Leadership Program Selection," Adm. Issues J. Educ. Pract. Res., vol. 4, no. 1, Apr. 2014, doi: 10.5929/2014.4.1.4.

25. B. L. Watson, "A descriptive study of enrollment marketing strategies for four -year public colleges and universities." Accessed: Mar. 26, 2019. [Online]. Available: https://digitalscholarship.unlv.edu/rtds/3108.

26. P. S. D. Aluwihare and R. Manoshika, "Addressing the issues of low student enrollment - The case of the Kandy Regional Centre of the Open University of Sri Lanka," Asian Assoc. Open Univ. J., vol. 8, no. 1, pp. 103-115, Mar. 2013, doi: 10.1108/aaouj-08-01-2013b010.

27. F. Maringe, "Interrogating the crisis in higher education marketing: The CORD model," Int. J. Educ. Manag., vol. 19, no. 7, pp. 564-578, 2005, doi: $10.1108 / 09513540510625608$. 
28. G. Bapat and R. Chitnis, "To study the effectiveness of university website for university admissions in COVID-19 crisis." Shodh Sarita, Lucknow, p. 12, 2020.

29. G. S. Bapat, S. S. Gankar, A. Professor, and F. of Management, "How students make choice of Universities: Understanding students decision making with reference to Digital Media." Accessed: Dec. 31, 2019. [Online]. Available: http://www.nacacnet.org/. 